\title{
Painful trigeminal neuropathy associated with anti-Plexin D1 antibody
}

Takayuki Fujii, MD, PhD, Ryo Yamasaki, MD, PhD, Yukino Miyachi, MSc, Kyoko linuma, MSc, Yu Hashimoto, MD, Noriko Isobe, MD, PhD, Takuya Matsushita, MD, PhD, and Jun-ichi Kira, MD, PhD

Neurol Neuroimmunol Neuroinflamm 2020;7:e819. doi:10.1212/NXI.0000000000000819

\section{Abstract}

\section{Objective}

To determine whether anti-Plexin D1 antibody (Plexin D1-immunoglobulin G [IgG]), which is associated with limb and trunk neuropathic pain (NP) and binds to pain-conducting small unmyelinated dorsal root ganglion (DRG) neurons, exists in patients with idiopathic painful trigeminal neuropathy (IPTN) and whether Plexin D1-IgG binds to trigeminal ganglion (TG) neurons.

\section{Methods}

We enrolled 21 consecutive patients with IPTN and 35 age- and sex-matched controls without NP (25 healthy persons and 10 with neurodegenerative diseases). We measured serum Plexin D1-IgG using a mouse DRG tissue-based indirect immunofluorescence assay (IFA) and by Western blotting (WB) using a recombinant human Plexin D1 (rhPlexin D1) accompanied by immunoadsorption tests with rhPlexin D1. The reactivity of Plexin D1-IgG toward mouse TG, brain, heart, and kidney was assessed by tissue-based IFAs.

\section{Results}

Serum Plexin D1-IgG was detected more frequently in IPTN than in controls by both IFA and WB (14.3\% vs $0 \%, p=0.048)$. Three Plexin D1-IgG-positive patients also had limb or trunk NP and commonly showed tongue pain. In tissue-based IFAs, IgG from 2 Plexin D1IgG-positive patients immunostained small TG neurons, which was prevented by preincubation with rhPlexin D1. Moreover, Plexin D1-IgG immunostaining mostly colocalized with isolectin B4-positive pain-conducting unmyelinated TG neurons. IFAs of other tissues with the same IgG revealed weak immunoreactivity only in endothelial cells, which was prevented by preincubation with rhPlexin D1.

\section{Conclusions}

Plexin D1-IgG, which binds to pain-conducting small TG neurons in addition to DRG neurons, can be present in IPTN as well as limb and trunk NP.

\author{
Correspondence \\ Dr. Kira \\ kira@neuro.med.kyushu-u.ac.jp
}




\section{Glossary}

DRG = dorsal root ganglion; HC = healthy control; IB4 = isolectin B4; ICHD-3 = International Classification of Headache Disorders 3rd edition; IFA = immunofluorescence assay; IgG = immunoglobulin G; IPTN = idiopathic painful trigeminal neuropathy; IVIg = IV immunoglobulin; NCS = nerve conduction study; NFH = neurofilament heavy chain; NP = neuropathic pain; PE = plasma exchange; rhPlexin D1 = recombinant human Plexin D1; TG = trigeminal ganglion; $\mathbf{T N}=$ trigeminal nerve; WB $=$ Western blotting.

Painful trigeminal neuropathy (PTN) presents with facial pain that coincides with the distribution of the trigeminal nerves (TNs). PTN develops in a variety of underlying conditions, but its pathomechanism is frequently undetermined. The International Classification of Headache Disorders 3rd edition (ICHD-3) defines such cases with unknown mechanism as idiopathic PTN (IPTN). ${ }^{1}$

We recently reported anti-Plexin D1 antibody (Plexin D1immunoglobulin $\mathrm{G}[\operatorname{IgG}]$ ) in the sera of $10 \%$ of patients with limb and trunk neuropathic pain (NP). ${ }^{2}$ Plexin D1-IgG binds to and exerts cytotoxic effects against isolectin B4 (IB4)-positive pain-conducting small unmyelinated dorsal root ganglion (DRG) neurons. ${ }^{2} \mathrm{NP}$ was improved in all Plexin D1-IgG-positive cases treated with plasma exchange. ${ }^{2} \mathrm{NP}$ occasionally manifests facial pain; therefore, we assessed whether Plexin D1-IgG exists in patients with IPTN and determined whether Plexin D1-IgG binds to trigeminal ganglion (TG) neurons.

\section{Methods}

\section{Patients}

We enrolled 21 consecutive patients with IPTN who attended our clinic between 2008 and 2019, and we reviewed their medical records. An IPTN diagnosis was based on the established criteria $^{1}$ : unilateral or bilateral facial pain colocalizing with one or both TNs, clinically evident positive (hyperalgesia and allodynia) and/or negative (hypesthesia and hypoalgesia) signs of TN dysfunction, no identified cause, and not better accounted for by another ICHD-3 diagnosis. Patients with some underlying diseases were not excluded unless the mechanism causing PTN was established. As controls, 35 ageand sex-matched subjects without NP were used ( 25 healthy persons and 10 with neurodegenerative diseases).

\section{Standard protocol approvals, registrations, and patient consents}

This study was approved by the Ethical Committee of Kyushu University (\#29-40 and \#30-164). All patients and controls provided written informed consent. Animal experiments were performed according to the protocols approved by the Institutional Animal Care and Use Committee at Kyushu University (A19-109).

\section{Plexin D1-IgG detection}

For all participants, serum Plexin D1-IgG was measured by both mouse DRG tissue-based indirect immunofluorescence assays (IFAs) and Western blotting (WB) using recombinant human Plexin D1 (rhPlexin D1) accompanied by immunoadsorption tests with rhPlexin D1 (R\&D Systems, Minneapolis). ${ }^{2}$ Before testing, patients' sera were preabsorbed with mouse liver powder (Rockland, Gilbertsville). ${ }^{3}$

\section{Mouse tissue-based IFAs}

IFAs were conducted using patient IgG and $4-\mu \mathrm{m}$ paraffin sections processed from $10 \%$ buffered formalin-fixed adult male C57BL/6 mouse tissues (10-12 weeks old). ${ }^{2}$ We also performed double immunostaining of TG neurons with patient IgG and Alexa Fluor 594-conjugated anti-IB4 (Thermo Fisher Scientific, Waltham, 1:1,000) and with patient $\operatorname{IgG}$ and antineurofilament heavy chain (NFH) (Covance, Princeton, 1:500).

\section{Data availability}

Any data not published within the article will be shared in anonymized form by request from any qualified investigator.

\section{Results}

\section{Detection of Plexin D1-IgG in IPTN}

Serum Plexin D1-IgG detected by both IFA and WB was more frequent in patients with IPTN than in controls $(3 / 21$ [14.3\%] vs $0 / 35[0 \%], p=0.048$ ) (figure 1 and table). The overall coincidence rate of positive WB and IFA results was $98.2 \%$ $(55 / 56,1$ control had an immunoreactive IgG band on WB but negative immunoreactivity to mouse DRG). Three patients who were Plexin D1-IgG-positive also had limb or trunk NP and commonly showed tongue pain, which was more frequent compared with patients with IPTN who were Plexin D1IgG-negative ( $100 \%$ vs $11.1 \%, p=0.03)$ (table). Otherwise, no difference was found in any parameter examined between the 2 groups. Here, we present 3 IPTN cases with Plexin D1-IgG.

\section{Case 1}

A 64-year-old woman had a 15-year history of persistent pain and numbness in her tongue and perioral area, which gradually spread to all 3 divisions of bilateral TNs and both upper limbs. Neurologic examination revealed a decreased sensation to pinprick and light touch in all TN divisions and the upper limbs. A nerve conduction study (NCS) showed decreased sensory action potentials in her upper limbs. Bilateral blink reflexes showed delayed R1 and R2 responses. IV immunoglobulin (IVIg) administration did not improve her symptoms.

\section{Case 2}

Two months before admission, a 46-year-old woman with atopic myelitis developed persistent pain and numbness of 
A

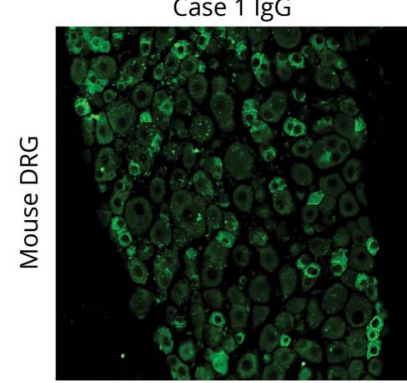

Case 1 IgG + rhPlexin D1

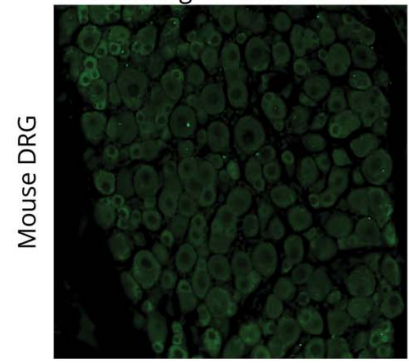

B

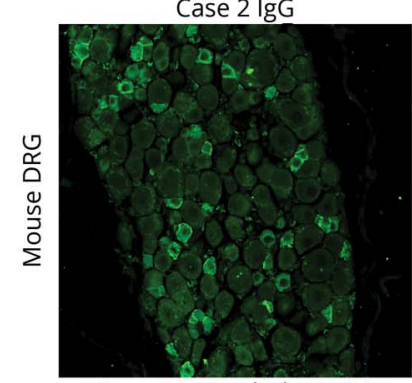

Case 2 lgG + rhPlexin D1

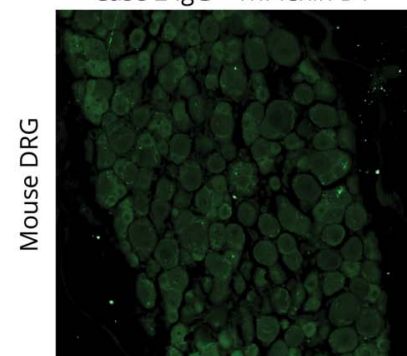

C

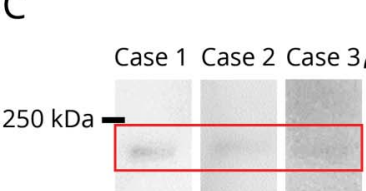

$150 \mathrm{kDa}-$
DAPI

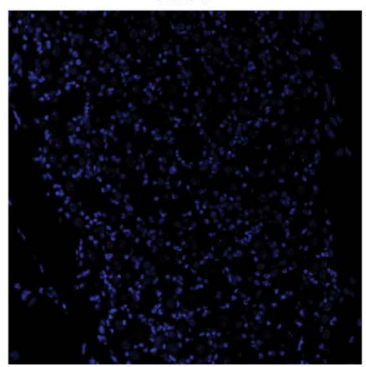

DAPI

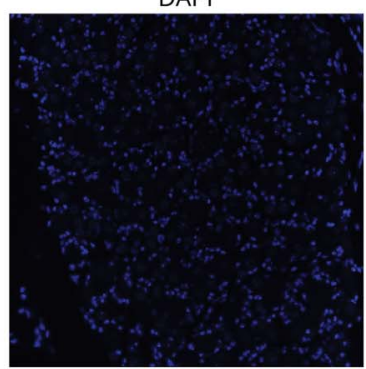

DAPI

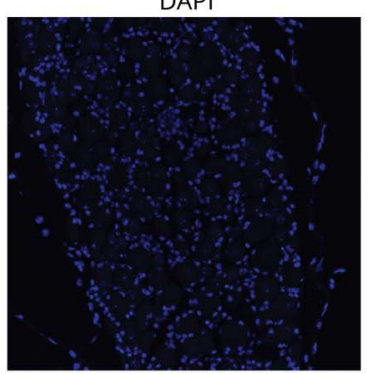

DAPI

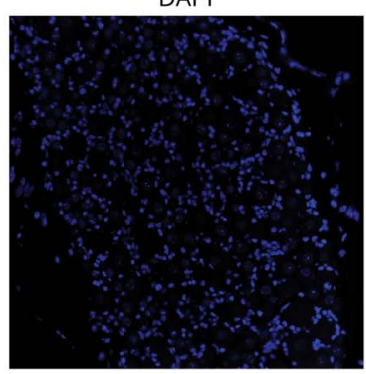

Patients with IPTN

without Plexin D1-lgG Healthy controls

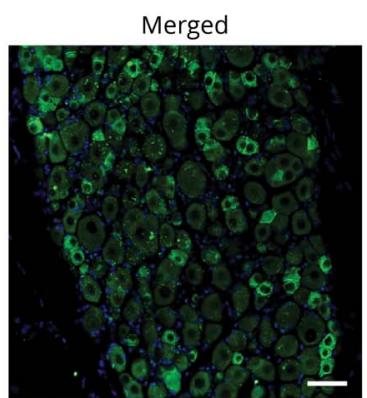

Merged

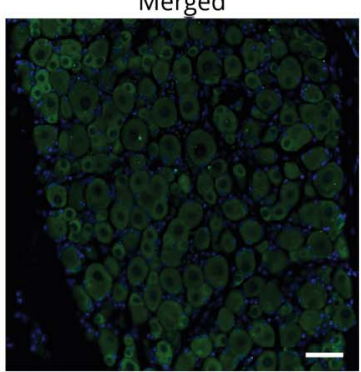

Merged

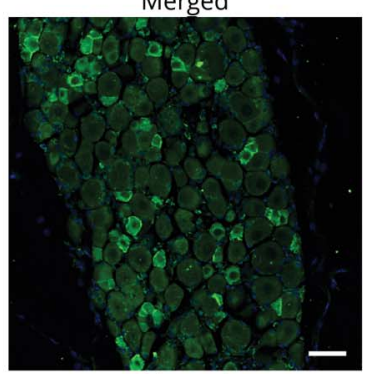

Merged

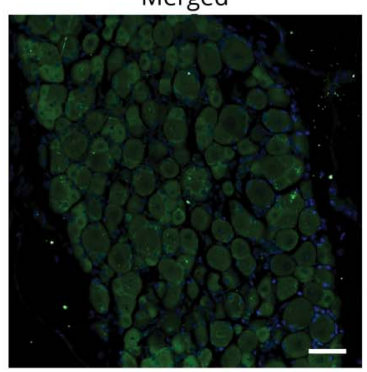

Anti-human Plexin D1 Plexin D1
(A) IFA with mouse DRG for case 1. IgG from case 1 (green) bound to small DRG neurons (upper images). The immunostaining (green) of small DRG neurons by IgG from case 1 was prevented by preincubation with rhPlexin D1 (2 $\mathrm{gg} / \mathrm{mL})$ (lower images). Nuclei are counterstained with 4',6diamidino-2-phenylindole (DAPI) (blue). (B) IFA with mouse DRG for case 2 . IgG from case 2 (green) bound to small DRG neurons (upper images). The immunostaining (green) of small DRG neurons by IgG from case 2 was prevented by preincubation with rhPlexin D1 $(2 \mu \mathrm{g} / \mathrm{mL})$ (lower images). Nuclei are counterstained with DAPI (blue). (C) WB analysis using rhPlexin D1 and IgG from cases 1, 2, and 3, 3 patients with IPTN without Plexin D1-IgG, 3 healthy controls, 3 patients with neurodegenerative diseases, and a commercial anti-human Plexin D1 antibody. WB of rhPlexin D1 with IgG samples from cases 1, 2, and 3 showed a common immunoreactive band between 150 and $250 \mathrm{kDa}$, similar to the commercial anti-human Plexin D1 antibody (R\&D Systems, Minneapolis). All other samples were nonreactive. Scale bars: (A and $B$ ) = $50 \mu \mathrm{m}$. DRG = dorsal root ganglion; IFA = immunofluorescence assay; IPTN = idiopathic painful trigeminal neuropathy; ND = neurodegenerative diseases; Plexin D1-IgG = antiPlexin D1 antibody; rhPlexin D1 = recombinant human Plexin D1; WB = Western blotting. the tongue, face, and a girdle-like sensation around midtrunk. Neurologically, she had hypesthesia in the tongue, face, and mid-trunk on admission. Spinal cord MRI revealed T2 hyperintense lesions at the level of Th8, whereas cranial MRI showed no relevant lesions. Her pain in the tongue, face, and mid-trunk was relieved by a combined administration of corticosteroids, azathioprine, and analgesics.

\section{Case 3}

An 81-year-old woman with a history of hepatitis B virusrelated liver cancer presented with tingling in her tongue and the soles of her feet, which she had experienced over the preceding 12 years. Neurologic examination revealed a decreased sensation to pinprick in her tongue and feet soles but preserved vibratory sensation and normal deep tendon reflexes. NCS showed normal findings. Therefore, her 
Table Clinical features of patients with IPTN with and without Plexin D1-lgG

\begin{tabular}{|c|c|c|c|c|c|}
\hline & $\begin{array}{l}\text { Total patients with } \\
\text { IPTN }(\mathbf{N}=\mathbf{2 1})\end{array}$ & $\begin{array}{l}\text { Patients with IPTN with } \\
\text { Plexin D1-IgG }(n=3)\end{array}$ & $\begin{array}{l}\text { Patients with IPTN without } \\
\text { Plexin D1-IgG }(n=18)\end{array}$ & $p^{u n c o r r a}$ & $p^{\text {corra }}$ \\
\hline Female, n (\%) & $14 / 21(66.7)$ & $3 / 3(100.0)$ & $11 / 18(61.1)$ & NS & NS \\
\hline $\begin{array}{l}\text { Age at the time of serum } \\
\text { sampling (mean } \pm S D), y\end{array}$ & $62.8 \pm 14.8$ & $64.0 \pm 18.0$ & $62.6 \pm 14.8$ & NS & NS \\
\hline Age at onset (mean \pm SD), y & $57.9 \pm 15.3$ & $54.7 \pm 12.5$ & $58.4 \pm 16.0$ & NS & NS \\
\hline $\begin{array}{l}\text { Disease duration at the time of } \\
\text { serum sampling (mean } \pm \text { SD), y }\end{array}$ & $4.9 \pm 5.4$ & $9.3 \pm 8.1$ & $4.2 \pm 4.8$ & NS & NS \\
\hline \multicolumn{6}{|l|}{ Localization of pain, $\mathbf{n}(\%)$} \\
\hline v1 & $11 / 21(52.4)$ & $0 / 3(0.0)$ & $11 / 18(61.1)$ & NS & NS \\
\hline V2 & $18 / 21(85.7)$ & $2 / 3(66.7)$ & $16 / 18(88.9)$ & NS & NS \\
\hline V3 & $18 / 21(85.7)$ & $3 / 3(100.0)$ & $15 / 18(83.3)$ & NS & NS \\
\hline Tongue & $5 / 21(23.8)$ & $3 / 3(100.0)$ & $2 / 18(11.1)$ & 0.0075 & 0.03 \\
\hline \multicolumn{6}{|l|}{ Laterality of pain, n (\%) } \\
\hline Unilateral & $10 / 21(47.6)$ & $0 / 3(0.0)$ & $10 / 18(55.6)$ & NS & NS \\
\hline Bilateral & $11 / 21(52.4)$ & $3 / 3(100.0)$ & $8 / 18(44.4)$ & NS & NS \\
\hline \multicolumn{6}{|l|}{ Pain characters, n (\%) } \\
\hline Tingling & $18 / 21(85.7)$ & $3 / 3(100.0)$ & $15 / 18(83.3)$ & NS & NS \\
\hline Burning & $1 / 21(4.8)$ & $0 / 3(0.0)$ & $1 / 18(5.6)$ & NS & NS \\
\hline Aching & $2 / 21(9.5)$ & $0 / 3(0.0)$ & $2 / 18(11.1)$ & NS & NS \\
\hline \multicolumn{6}{|l|}{$\begin{array}{l}\text { Abnormalities in clinical sensory } \\
\text { testing, } \mathrm{n}(\%)\end{array}$} \\
\hline Hypesthesia & $20 / 21(95.2)$ & $3 / 3(100.0)$ & $17 / 18(94.4)$ & NS & NS \\
\hline Hyperesthesia/allodynia & $2 / 21(9.5)$ & $1 / 3(33.3)$ & $1 / 18(5.6)$ & NS & NS \\
\hline History of allergy, n (\%) & $6 / 21(28.6)$ & $2 / 3(66.7)$ & $4 / 18(22.2)$ & NS & NS \\
\hline $\begin{array}{l}\text { Abnormalities of the blink } \\
\text { reflex, } n(\%)\end{array}$ & $6 / 9(66.7)$ & $1 / 1(100.0)$ & $5 / 8(62.5)$ & NS & NS \\
\hline
\end{tabular}

Abbreviation: IPTN = idiopathic painful trigeminal neuropathy

The Mann-Whitney $U$ test was used to compare continuous variables, and the $\chi^{2}$ test or Fisher exact probability test (when criteria for the $\chi^{2}$ test were not fulfilled) was used to compare categorical variables between each group. Statistical significance was set at $p<0.05$. Uncorrected $p$ values $\left(p^{\text {uncorr }}\right)$ were corrected by multiplying them by the number of comparisons in the same categories (Bonferroni-Dunn correction) to calculate corrected $p$ values ( $p^{\text {corr }}$ ).

${ }^{\text {a }}$ Patients with IPTN with Plexin D1-IgG vs patients with IPTN without Plexin D1-IgG.

diagnosis was small fiber neuropathy of unknown etiology. She received an analgesic agent only without immunotherapy to avoid hepatitis B virus reactivation.

\section{Tissue-based IFA}

IgG from cases 1 and 2 bound to small TG neurons in IFAs (figure 2, A and B). Preincubation with rhPlexin D1 prevented the staining of small TG neurons by the patients' IgG (figure 2, A and B), indicating that Plexin D1-IgG bound to small TG neurons. Dual labeling revealed that IB4 immunostaining, a marker for pain-conducting unmyelinated neurons, mostly colocalized with patient IgG binding (figure 2C). Conversely, patient IgG did not colocalize with $\mathrm{NFH}$, a marker for myelinated neurons (figure 2D). These findings indicated that Plexin D1-IgG binds to pain-conducting unmyelinated TG neurons in addition to DRG. ${ }^{2}$ IFAs of mouse brain, heart, and kidney tissues with patient IgG demonstrated weak immunoreactivity only in endothelial cells, which was prevented by preincubation with rhPlexin D1 (figure 2E).

\section{Discussion}

The main findings of the present study are as follows: (1) a small fraction of patients with IPTN had Plexin D1-IgG and (2) Plexin D1-IgG bound directly to small TG neurons, especially IB4-positive pain-conducting unmyelinated neurons.

Plexin D1 mRNA is present at low levels in various normal adult tissues. ${ }^{4}$ Recent studies found Plexin D1 mRNA and 
Figure 2 IFA using mouse tissues and IgG from patients with IPTN with Plexin D1-IgG

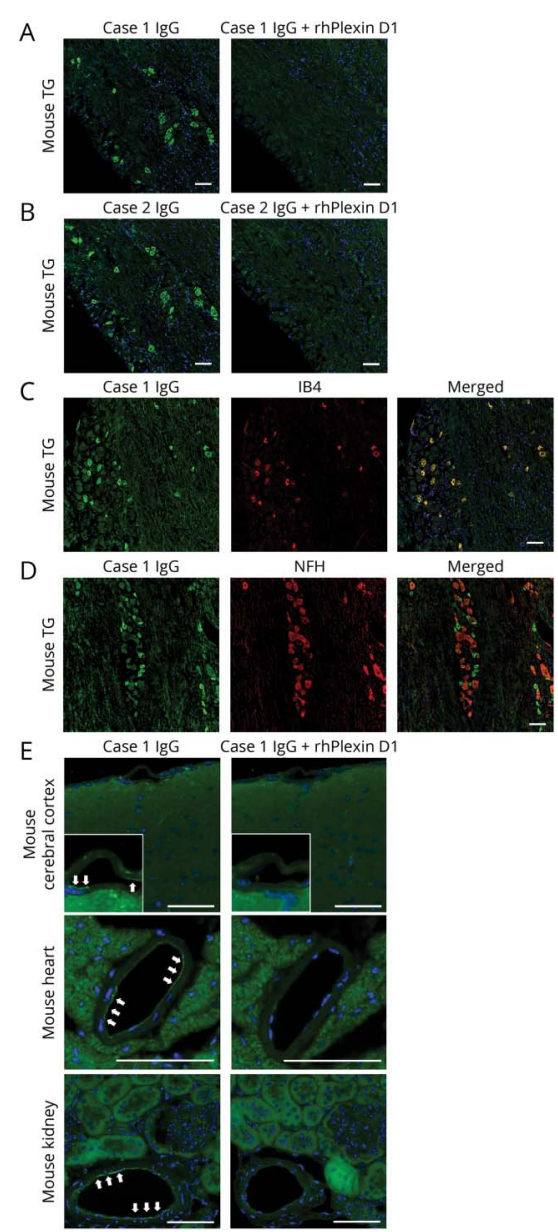

(A) IFA with mouse TG for case 1. IgG from case 1 (green) bound to small TG neurons (left image). The immunostaining (green) of small TG neurons by IgG from case 1 was prevented by preincubation with rhPlexin D1 $(2 \mu \mathrm{g} / \mathrm{mL})$ (right image). Nuclei are counterstained with 4',6-diamidino-2-phenylindole (DAPI) (blue). (B) IFA with mouse TG for case 2. IgG from case 2 (green) bound to small TG neurons (left image). The immunostaining (green) of small TG neurons by IgG from case 2 was prevented by preincubation with rhPlexin D1 $(2 \mu \mathrm{g} / \mathrm{mL}$ ) (right image). Nuclei are counterstained with DAPI (blue). (C) Immunostaining for IB4 (red), a marker of unmyelinated C-fiber type TG neurons, mostly colocalized with IgG (green) in a representative patient with IPTN (case 1). (D) Immunostaining for NFH (red), a marker of myelinated A $\beta$ and $A \delta$ fiber type TG neurons, did not colocalize with IgG binding (green) in case 1. (E) IFAs with the mouse brain, heart, and kidney using IgG from a representative patient with IPTN (case 1). IgG from case 1 (green) restrictedly bound to endothelial cells (white arrows) in the cerebral cortex (upper image), heart (middle image), and kidney (lower image). The weak immunostaining (green) of endothelial cells by IgG from case 1 was prevented by preincubation with rhPlexin D1 $(2 \mu \mathrm{g} / \mathrm{mL})$. Nuclei are counterstained with DAPI (blue). Scale bars: $(A-E)=50 \mu \mathrm{m}$. IB4 = isolectin B4; IFA = immunofluorescence assay; IPTN = idiopathic painful trigeminal neuropathy; NFH = neurofilament heavy chain; Plexin D1-IgG = anti-Plexin D1 antibody; rhPlexin D1 = recombinant human Plexin D1; TG = trigeminal ganglion.

protein in normal adult human and mouse $\mathrm{DRG}^{2,5}$ but not in the normal adult human brain and heart. ${ }^{6}$ In our study, Plexin D1-IgG from patients with IPTN immunoreacted with DRG neurons but only weakly immunostained endothelial cells in the brain, heart, and kidney, which is largely consistent with previous findings. NP is attributable to preferential binding of Plexin D1-IgG to DRG neurons, although endothelial cell dysfunction in NP should also be carefully monitored. Transcriptome analyses of TG and DRG neurons revealed that Plexin D1 mRNA is significantly enriched in DRG compared with TG neurons. ${ }^{5}$ Therefore, limb and trunk pain may occur more frequently than facial pain in Plexin D1-IgG-positive cases.

IVIg was ineffective for pain relief in case 1, whereas a combined administration of corticosteroids and azathioprine improved pain in case 2 . The difference in disease duration (2 months vs 15 years) may explain the inconsistent effects of immunotherapy because long disease duration is associated with neural damage in autoantibody-mediated neuropathy. ${ }^{7}$ Alternatively, Plexin D1-IgG-mediated disease may be resistant to IVIg because some subclasses of IgG autoantibodies are reported to show resistance to IVIg. ${ }^{8}$

A study limitation is that we did not establish a cell-based assay for Plexin D1-IgG because transfection of various cell types, including human embryonic kidney 293 cells, with plasmids encoding Plexin D1 induced apoptosis. ${ }^{9}$ Establishment of a reliable cell-based assay for Plexin D1-IgG requires further study.

In conclusion, we have demonstrated the presence of Plexin D1-IgG in a small fraction of patients with IPTN and Plexin D1-IgG reactivity toward small TG neurons, which indicates that Plexin D1-IgG-related NP could manifest as facial pain in addition to limb and trunk pain.

\section{Acknowledgment}

The authors thank Jeremy Allen, $\mathrm{PhD}$, from the Edanz Group (edanzediting.com/ac) for editing a draft of this manuscript.

\section{Study funding}

This study was funded in part by grants from the Japan Society for the Promotion of Science (JSPS) KAKENHI (Grant Nos. 19H01045 and 19K17037).

\section{Disclosure}

T. Fujii is supported by grants from JSPS KAKENHI (Grant No. 19K17037), Mitsubishi Tanabe Pharma, Osoegawa Neurology Clinic, Bayer Yakuhin, Ltd., and the Japan Blood Products Organization and received speaker honoraria payments from the Takeda Pharmaceutical Company and Eisai. R. Yamasaki is supported by a grant from JSPS KAKENHI (Grant No. 19K07963). Y. Miyachi, K. Iinuma, and Y. Hashimoto report no disclosures. N. Isobe is supported by grants from Mitsubishi Tanabe Pharma, Osoegawa Neurology Clinic, Bayer Yakuhin, Ltd., and the Japan Blood Products Organization. T. Matsushita received speaker honoraria payments from Mitsubishi Tanabe Pharma, the Takeda Pharmaceutical Company, and Biogen Japan. J.-i. Kira is supported by grants from JSPS KAKENHI (Grant No. 19H01045) and Health and Labour Sciences Research Grants on Intractable Diseases [H29-Nanchitou (Nan)-Ippan-043] and received consultancy fees, speaking fees, and/or honoraria from 
Novartis Pharma, Mitsubishi Tanabe Pharma, Boehringer Ingelheim, Teijin Pharma, Takeda Pharmaceutical Company, Otsuka Pharmaceutical, Astellas Pharma, Pfizer Japan, and Eisai. Go to Neurology.org/NN for full disclosures.

\section{Publication history}

Received by Neurology: Neuroimmunology \& Neuroinflammation March 24, 2020. Accepted in final form May 14, 2020.

\section{Appendix Authors}

\begin{tabular}{lll}
\hline Name & Location & Contribution \\
\hline $\begin{array}{l}\text { Takayuki } \\
\text { Fujii, MD, PhD }\end{array}$ & $\begin{array}{l}\text { Kyushu } \\
\text { University, } \\
\text { Fukuoka, Japan }\end{array}$ & $\begin{array}{l}\text { Designed and conceptualized the } \\
\text { study; analyzed the data; and } \\
\text { drafted the manuscript for } \\
\text { intellectual content }\end{array}$ \\
\hline $\begin{array}{l}\text { Ryo } \\
\text { Yamasaki, } \\
\text { MD, PhD }\end{array}$ & $\begin{array}{l}\text { Kyushu } \\
\text { University, }\end{array}$ & Analyzed and interpreted the data \\
\hline $\begin{array}{l}\text { Yukino } \\
\text { Miyachi, MSc }\end{array}$ & $\begin{array}{l}\text { Kyushu } \\
\text { University, } \\
\text { Fukuoka, Japan }\end{array}$ & $\begin{array}{l}\text { Major role in data acquisition, IFA, } \\
\text { and WB }\end{array}$ \\
\hline $\begin{array}{l}\text { Kyoko } \\
\text { linuma, MSc }\end{array}$ & $\begin{array}{l}\text { Kyushu } \\
\text { University, }\end{array}$ & $\begin{array}{l}\text { Major role in data acquisition and } \\
\text { WB }\end{array}$ \\
\hline $\begin{array}{l}\text { Yukuoka, Japan } \\
\text { Hashimoto, } \\
\text { MD }\end{array}$ & $\begin{array}{l}\text { Kyushu } \\
\text { University, } \\
\text { Fukuoka, Japan }\end{array}$ & $\begin{array}{l}\text { Major role in data acquisition and } \\
\text { clinical data of patients }\end{array}$ \\
\hline
\end{tabular}

Appendix (continued)

\begin{tabular}{lll}
\hline Name & Location & Contribution \\
\hline $\begin{array}{l}\text { Noriko Isobe, } \\
\text { MD, PhD }\end{array}$ & $\begin{array}{l}\text { Kyushu } \\
\text { University, } \\
\text { Fukuoka, Japan }\end{array}$ & $\begin{array}{l}\text { Major role in data acquisition and } \\
\text { clinical data of patients }\end{array}$ \\
\hline $\begin{array}{l}\text { Takuya } \\
\text { Matsushita, } \\
\text { MD, PhD }\end{array}$ & $\begin{array}{l}\text { Kyushu } \\
\text { Eniversity, }\end{array}$ & $\begin{array}{l}\text { Major role in data acquisition and } \\
\text { clinical data of patients }\end{array}$ \\
\hline $\begin{array}{l}\text { Jun-ichi Kira, Japan } \\
\text { MD, PhD }\end{array}$ & $\begin{array}{l}\text { Kyushu } \\
\text { University, } \\
\text { Fukuoka, Japan }\end{array}$ & $\begin{array}{l}\text { Designed and conceptualized the } \\
\text { study; interpreted the data; and } \\
\text { revised the manuscript for } \\
\text { intellectual content }\end{array}$ \\
\hline
\end{tabular}

\section{References}

1. Headache Classification Committee of the International Headache Society (IHS) The International Classification of Headache Disorders, 3rd edition. Cephalalgia 2018;38:1-211.

2. Fujii T, Yamasaki R, Iiunuma $\mathrm{K}$, et al. A novel autoantibody against Plexin D1 in patients with neuropathic pain. Ann Neurol 2018;84:208-224.

3. Prineas JW, Parratt JDE. Multiple sclerosis: serum anti-CNS autoantibodies. Mult Scler 2018;24:610-622.

4. Rehman M, Gurrapu S, Cagnoni G, et al. PlexinD1 is a novel transcriptional target and effector of notch signaling in cancer cells. PLoS One 2016;11:e0164660.

5. Megat S, Ray PR, Tavares-Ferreira D, et al. Differences between dorsal root and trigeminal ganglion nociceptors in mice revealed by translational profiling. J Neurosci 2019;39:6829-6847.

6. Roodink I, Verrijp K, Raats J, et al. Plexin D1 is ubiquitously expressed on tumor vessels and tumor cells in solid malignancies. BMC Cancer 2009;9:297.

7. Ogata H, Yamasaki R, Hiwatashi A, et al. Characterization of IgG4 anti-neurofascin 155 antibody-positive polyneuropathy. Ann Clin Transl Neurol 2015;2:960-971.

8. Devaux JJ, Miura Y, Fukami Y, et al. Neurofascin-155 IgG4 in chronic inflammatory demyelinating polyneuropathy. Neurology 2016;86:800-807.

9. Luchino J, Hocine M, Amoureux MC, et al. Semaphorin 3E suppresses tumor cell death triggered by the Plexin D1 dependence receptor in metastatic breast cancers. Cancer Cell 2013;24:673-685. 


\title{
Neurology \\ Neuroimmunology \& Neuroinflammation
}

\author{
Painful trigeminal neuropathy associated with anti-Plexin D1 antibody \\ Takayuki Fujii, Ryo Yamasaki, Yukino Miyachi, et al. \\ Neurol Neuroimmunol Neuroinflamm 2020;7; \\ DOI 10.1212/NXI.0000000000000819
}

This information is current as of June 25, 2020

\section{Updated Information \& Services}

References

Citations

Subspecialty Collections

Permissions \& Licensing

Reprints including high resolution figures, can be found at:

http://nn.neurology.org/content/7/5/e819.full.html

This article cites 9 articles, 1 of which you can access for free at: http://nn.neurology.org/content/7/5/e819.full.html\#\#ref-list-1

This article has been cited by 2 HighWire-hosted articles: http://nn.neurology.org/content/7/5/e819.full.html\#\#otherarticles

This article, along with others on similar topics, appears in the following collection(s):

Autoimmune diseases

http://nn.neurology.org//cgi/collection/autoimmune_diseases Neuropathic pain

http://nn.neurology.org//cgi/collection/neuropathic_pain

Information about reproducing this article in parts (figures,tables) or in its entirety can be found online at:

http://nn.neurology.org/misc/about.xhtml\#permissions

Information about ordering reprints can be found online: http://nn.neurology.org/misc/addir.xhtml\#reprintsus

Neurol Neuroimmunol Neuroinflamm is an official journal of the American Academy of Neurology.

Published since April 2014, it is an open-access, online-only, continuous publication journal. Copyright

Copyright (C) 2020 The Author(s). Published by Wolters Kluwer Health, Inc. on behalf of the American

Academy of Neurology.. All rights reserved. Online ISSN: 2332-7812.

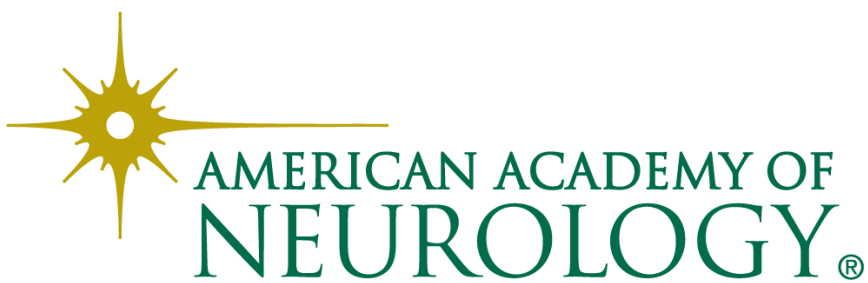

